\title{
At Least in Fighting Terrorism, Transatlantic Cooperation Is Working
}

By Philippe Coessens ${ }^{*}$

While disagreements between the United States and the European Union on a range of global issues have recently attracted attention, cooperation between the two sides of the Atlantic on counter-terrorism has been relatively successful. There can be no doubt that this is an area in which the European Union and the United States share common goals.

It is clear that terrorism and associated problems such as drug trafficking, money laundering, illegal immigration, and organized crime are very much global issues. So the European Union's anti-terrorism efforts can be said to have had a positive impact on the world in general, and on the United States in particular. This applies not only to the Union's internal achievements but also to its efforts to strengthen cooperation with other countries and its participation in multilateral forums such as the United Nations and the Group of Eight leading industrial nations.

The European Union set to work on a new anti-terrorism initiative immediately after the terrorist attacks of September 11, 2001, convening a special meeting of the European Council barely a week later and coming up with a comprehensive action plan to support the United States in the face of the terrorist attacks. The plan contained a series of actions aimed at enhancing police and judicial cooperation, developing international legal instruments, stepping up efforts to cut off terrorist financing worldwide (by immediately freezing assets of a substantial number of terrorist organizations), strengthening air security, and contributing to the systematic evaluation of relations with third countries in the light of their position on terrorism.

Since then, the European Union and the United States have concluded a series of important bilateral agreements on police and judicial cooperation (notably agreements between Europol and the United States reinforcing the capability of law enforcement authorities to exchange data), as well as on mutual legal assistance and extradition. These, once fully in force, will make it easier to bring to justice terrorists and other serious criminals in the jurisdictions where they are wanted.

Inside the European Union, the focus has been on judicial cooperation between member states, increased cooperation between police and intelligence

\footnotetext{
* Philippe Coessens is the Head of Political, Academic, Justice, and Home Affairs at the Delegation of the European Commission in Washington, D.C. From 1998 to 2003, he was Head of Unit "European Correspondent" in the External Relations Directorate General. Before joining the Commission in 1991, he served in the Belgian Ministry of Foreign Affairs. This article first appeared in the Fall 2003 issue of European Affairs, a publication of the European Institute.
} 
services, border control, and measures to counter the financing of terrorism. Key achievements in these areas include agreement on a common European arrest warrant and an EU framework decision on combating terrorism, which includes a definition of terrorist offenses; a more closely coordinated scale of penalties; a common EU list of worldwide terrorist organizations; and mutual recognition of orders freezing the property of terrorists or securing evidence against them. Plans are also under way to develop more secure visas and travel documents.

None of these agreements was easy to achieve. They are, however, already having real operational effects by improving the legal framework for fighting crime and terrorism throughout the European Union. The combination of these new instruments is effectively denying safe haven to those who finance, plan, support, or commit terrorist acts. In addition, the European Union has approved revised recommendations by the Financial Action Task Force aimed at stemming the flow of funds to terrorists and further cracking down on money laundering.

The Union has also been developing a multi-faceted and more coordinated approach aimed at incorporating the fight against terrorism into all aspects of its foreign policy. For example, it is conducting threat analyses of various countries and regions (Central and Latin America, South and Southeast Asia) that are leading to concrete policy recommendations.

In line with these recommendations, the European Union is launching pilot projects to help three priority countries (Indonesia, Pakistan, and the Philippines) curb terrorist financing, strengthen law enforcement, and develop more effective judicial systems. These countries and actions were chosen in consultation with the UN Counter-Terrorism Committee so as to assist their governments to implement UN Security Council Resolution 1373 of September 2001, which called for wide-ranging measures to fight terrorism.

A second important step has been the introduction of anti-crime and anti-terrorism clauses in EU trade and cooperation agreements. Such clauses require the parties to exchange information on terrorist groups and their support organizations, with a view to preventing or punishing acts of terrorism. These provisions are being gradually included in agreements with Chile, Algeria, Egypt, and Lebanon, and currently figure in difficult negotiations for agreements with Syria, Iran, and the Gulf Cooperation Council.

The Group of Eight (G8), which includes four EU member states (Britain, France, Germany, and Italy), along with representatives of the EU institutions, has also been quick to work toward implementing UN Security Council Resolution 1373. The G8 immediately recognized the need to provide technical assistance to other countries to help them to build the necessary capabilities to fulfill their obligations under the resolution.

At its latest summit meeting, in Evian in June 2003, the G8 adopted an action plan that also concentrates on outreach activities and capacity building. 
The plan focuses on fighting terrorism in particular regions, such as South East and Central Asia, and in certain specific fields, such as reinforcing border security and equipping institutions to tackle money laundering and the financing of terrorist organizations.

More generally, the U.S.-EU political dialogue on the entire issue of terrorism has deepened. Justice, home affairs, and counter-terrorism officials now meet regularly, and cooperation has substantially improved since 9/11. A great deal of work is also being done on both sides of the Atlantic on measures to counter the proliferation of weapons of mass destruction and their acquisition by terrorist groups, and on how to deal with so-called rogue states.

The European Union also adopted an important policy document that lays out guiding principles and a concrete plan for further counter-terrorist action at a summit meeting in Thessaloniki in June. This plan sets the course for future action so that momentum in the fight against terror will not be lost.

The verdict on all these efforts to improve transatlantic cooperation in the fight against terrorism must at this point be "so far, so good." Since 9/11, cooperation has substantially improved. Intelligence has been flowing across the Atlantic in unprecedented volumes, a number of terrorist cells have been disrupted, and many suspected terrorists are being prosecuted in different European countries.

The European Union and the United States share the same values and objectives. We are now also sharing some of the same tools available to curb terrorist activity. After all the discussions we have had about different approaches to multilateralism on either side of the Atlantic, it is striking that in this field both sides are stressing the importance of the work of the United Nations and the Counter-Terrorism Committee. That shows that - on terrorism, at least - the European Union and the United States see eye-to-eye as actors in the international community. 